\title{
Magistrates, Doctors, and Monks: Satire in the Chinese Jestbook Xiaolin Guangji
}

\begin{abstract}
In most modern Chinese-English dictionaries, the term fengci - a word composed of two characters which originally meant "to chant" and "to stab" is often given as a direct translation of "satire." In the light of an etymological origin so notably different from its Latin counterpart, satura, one might be tempted to think that satire, in its commonly understood sense, does not exist in Chinese literature, especially of the premodern variety. This article takes social satire as its starting point, introducing and dealing with three recurring categories of character from the premodern Chinese jestbook Xiaolin Guangji, namely magistrates, doctors, and monks. The debased image in which such characters wallow, and the overturning of their value systems, are the two main features which best serve the purpose of satire, and in this article such features become the object of a comparative theoretical analysis in an attempt to establish a dialogue between the main themes of the aforementioned jokes and the Western concept of satire. The main purposes of this article are to point out the satirical (and not merely ridiculous or humorous) nature of the text, and at the same time to highlight a Chinese way of using it, which has apparently been neglected to date.
\end{abstract}

Keywords: Chinese literature, intertextuality, jestbooks, parody, satire, Xiaolin Guangji

Satire appears throughout the history of classical Chinese literature and encompasses all genres; one might even argue that any representative work of Chinese narrative contains at least some degree of satire, and that there is at least one representative satirical work for each literary genre (poetry, drama, essays, and so on). Therefore, we should not consider Chinese satire as a distinct genre, but rather as a feature, a continuum present in varying degrees and configurations in different works. The Chinese word for satire is fengci 諷刺, a word coming from a line in the Great Preface ( $D a X u$ 大序), the most authoritative commentary on the Book of Odes (Shijing 詩經); it originally meant "to criticize by means of an ode": 上以風化下, 下以風刺上 [By feng those above transform those below, also by feng those below criticize those above] (Owen 1992, 46). As is the case with many characters (tongjia 通假 “interchangeable homophones”), feng 風 “air, poem, ode” (but also "influence”) is interchangeable with feng 諷 “to chant” (but also "to 
criticize"; Owen 1992, 39). ${ }^{1}$ Confucius himself, apart from being considered the compiler of the Book of Odes, is thought to have highlighted its social power elsewhere: 詩可以興, 可以觀可以群, 可以怨 [An apt quotation from the Odes may serve to stimulate the imagination, to show one's breeding, to smooth over difficulties in a group and to give expression to complaints] (Confucius 2010, 17.9; my emphasis).

While it is true that satire (or its conceptualization) is rooted in poetry, it is however much easier to spot in the philosophical writings of the Pre-Qin (xianqin 先秦, up to 221 BC) era. Treaties from the various schools of thought often clarified their points of view through brief explanatory anecdotes, called yuyan 寓言 ("entrusted words"; this word would later come to mean "parables"), stylistically quite close to proper jokes, and often brimming with satirical content. The Daoist text Zhuangzi 莊子 records the first definition of yuyan: 寓言十九, 藉外論之。親 夫不為其子媒, 親夫舉之, 不若非父者也 [I entrust my words to others nine out of ten times, and I rely on external factors (or strangers) to expound my point. (Just as) A father does not act as a matchmaker for his son, because his recommendation would not be as convincing as someone who is not a father] (Guo 1985, 948; translation, emphasis, and interpolations in brackets are mine).

Yuyan, though often humorous in content, were used to prove a point, and not as simple jokes. In the same way, poetry's various incursions into humour were usually not for the mere purpose of laughter, but to voice dissatisfaction. The Book of Odes records a maxim according to which one should and should not use derision: 善戲謔兮, 不為虐兮 [When you make fun of someone, you should not be offensive] (my translation). The accepted theory is that yuyan were non-existent in the high literature of the Qin 秦 (221-206 BC) and Han 漢 (206 BC-AD 220) dynasties, when ruthless emperors damaged, both literally and spiritually, literary circles. Suffice it to remember that the first emperor, Qin Shihuang 秦始皇 (259-210 BC), ordered “burn the books and bury the scholars,” and that Emperor Han Wudi 漢武帝 (r. 187-140 BC) advocated “dismiss all other teachings and revere only the Confucians." These activities left the intellectuals worrying about much more serious matters than proving their point through humorous parables. As David Knechtges put it, "Confucians, particularly Han Confucians, were generally a stuffy and prudish lot” (1970-1971, 81). It follows that every trace of incongruity, every double entendre, and every voluntary pun was absent from orthodox teaching, and relegated to popular songs, court jesters, and so on.

1 The meaning of feng as “chant” is recorded in the Han 漢 dictionary Shuowen Jiezi 說文解字 (second century AD). 
In the Wei-Jin 魏晉 (AD 220-589) period, two major events contributed to breathing new life into this genre: firstly, the appearance of Handan Chun's 邯鄲淳 (132-225) The Forest of Laughs (Xiaolin 笑林), a collection of humorous anecdotes, which today is regarded as the first Chinese jestbook; secondly, the translation into Chinese of the Buddhist Hundred-Fable Sutra (Bai Yu Jing 百喻經). ${ }^{2}$ Satire (and humour in general), muzzled in orthodox literature, flourished in the many jestbooks which followed these two. ${ }^{3}$

It is from this perspective that I propose to analyse the Qing 清 (1644-1912) jestbook Extended Records from the Forest of Laughter (Xiaolin Guangi 笑林廣記; henceforth $X L G J)$, in terms of both satirical poems and stories. Its earliest extant version dates back to the fifty-sixth year of the Qianlong Reign 乾隆 (1791), and it can be considered one of the highest achievements in this specific literary format, an anthology containing more than six hundred jokes from at least three previous collections. ${ }^{4}$ The compiler of this collection hid his identity under the pseudonym Youxi Zhuren 遊戲主人 “The Master of Games,” but others quote him as Youxi Daoren 遊戲道人 “The Playful Learner of the Way." 5

\title{
1 Satirical poems
}

\begin{abstract}
Despite being well over sixty, an old prostitute kept on applying heavy ointments to herself, to curry favour with young boys. Afraid to reveal her white hair, she bundled it in a very respectable way, and covered it with a hat. This went unnoticed by the common people, and at the end of the day, she still managed to seduce someone. A famous literate mentioned this at a banquet, and jokingly modified a poem by $\mathrm{Du} F u$, to ridicule her: "At this venerable age she is still going strong and unable to relax, happy to entertain to the fullest tonight's noblemen. Worried about the hair on her temples, she learns to cover it respectably. Liquid pours from her vagina as if falling from a thousand cliffs, while her bound feet stand erect and cold like the peaks of two mountains. This time next year, who knows who will be here (with her)? Drunk, I take my own cock and look at it.” And everyone laughed. (XLGJ 1985, 257-258; my translation)
\end{abstract}

This joke goes to great lengths to modify a pre-existing text; as a parasitic literary form (a feature that it shares with satire), a joke can momentarily disguise itself as a different literary genre. The most attentive readers will recognize this

2 Chen and Cao (1981, 119-124).

3 For an all-encompassing anthology of selections from these jestbooks, see Wang (1956).

4 Namely Xiaozan 笑贊, Xiaodao 笑倒, Xiaofu 笑府; see Rea $(2015,22)$. However, XLGJ is mostly a rewriting of Xiaofu.

5 For example, Hsu Pi-Ching $(2015,7)$. 
text as a parody of a poem by the Tang 唐 poet Du Fu 杜甫 (712-770) entitled “At Cui's Villa in Lantian on the Double Ninth Festival” (Jiuri lantian Cuishi Zhuang 九日藍田崔氏莊):

As I age, I grieve over autumn and force myself to relax,

A good mood comes on me today, I have a full measure of delight with you.

Embarrassed that with this thinning hair my hat would be again blown off;

One might ask a bystander to tease me, so I straighten up my cap.

The Lan River comes from afar, falling from a thousand mountain streams, Jade Mountain's height matches the paired peaks in cold.

At this gathering next year, I wonder who will be hale?

Drunk, I take the ailanthus in hand and look at it carefully. (Owen 2016, 50)

One way to approach this text is to see how it reacts to the principle of textual cooperation. This principle, as theorized by Eco $(1979,67)$, revolves around a sort of game that the author wants the reader to win, thereby interpreting the text correctly. In order for this specific joke to work, some conditions are necessary:

- The recipient should be familiar with the subject of the poem. For this reason, the introductory remarks give us some background information.

- The recipient should be familiar with the original material - that is, Du Fu's poem - from which the parasitic text stems.

- The recipient should momentarily lose the game of textual cooperation: for a satisfactory result, the receiver is not supposed to recognize the joke as such from the beginning, nor to guess its punchline.

Our joke starts as a simple imitation; in fact, the first lines of the two texts look like two variations on the same poem. The elements of parody come forward only one by one, starting in the third line: the hair, the water, the bound feet, and the poor client's penis. All these images lead the poem astray from its original form, and finally allow the receiver to interpret the text as a joke, an imitation. This imitation, in turn, is not the ultimate purpose of the joke; were it so, we would not be facing a satire directed at the old prostitute, but merely a parody of Du Fu's poem.

Satirical poems take on a social edge in many cases, aiming to strike at public characters, albeit without calling them by name, and thus to epitomize them as representatives of an entire category. The following joke is an example:

There used to be a magistrate with no talent in running state affairs; being only interested in wine, he ran the state indolently, and his love for wealth led him to be cruel towards his subjects. The people hated him so much that they wrote a poem to ridicule him: "Lamps of black lacquered leather, half a day a firefly. A white tiger painted on a whitewashed wall, a black dragon written on yellow paper. He knocks on a mud chime stone with an eggplant, and he tries to play a wooden bell with a white gourd. He only knows money and alcohol, without considering what is just and what is right." (XLGJ 1985, 13; my translation) 
The mimesis of the joke is once again complete, and the reader is at a loss: this little text appears at first more similar to a poem than to a joke, and, apart from the last two lines, it seems a collection of rather disjointed images. The original text relies heavily on its prosodic structure, in which there is a rhyme for every two lines: chong 蟲 “insect” (as part of yinghuochong 螢火蟲 “firefly”), long 龍 “dragon,” zhong 鐘 “bell,” and gong 公 “right.” In order to enable us to identify the object of satire, the background context at the beginning of the joke comes to our assistance; but even so, the images appearing before our eyes make little or no sense unless we arrange them into couplets. "Lamps of black lacquered leather" is a reference to a popular song recorded by the scholar Tao Zongyi 陶宗儀 (1316-1403?), with which people voiced their disappointment about a corrupt magistrate. ${ }^{6}$ The second line appears as a corollary of the first one; in traditional Chinese medical science, fireflies were thought to be generated by rotting grass, ${ }^{7}$ hence someone who is "half a day a firefly" is probably someone who rots away for a considerable amount of time. In the following two lines, we supposedly witness two arts that the corrupt magistrate indulges in rather than administering state affairs, namely painting and calligraphy. The parallelism between the lines follows this scheme:

$\begin{array}{lllll}\text { colour } & \text { place } & \text { verb } & \text { colour } & \text { animal } \\ \text { 粉 } & \text { 墙 } & \text { 畫 } & \text { 白 } & \text { 虎 } \\ \text { “whitewashed” } & \text { “wall” } & \text { “to paint” } & \text { “white” } & \text { “tiger” (symbol of yin 陰) } \\ \text { 黃 } & \text { 紙 } & \text { 寫 } & \text { 鳥 } & \text { 龍 } \\ \text { “yellow” } & \text { “paper” } & \text { “to write” } & \text { "black” } & \text { “dragon” (symbol of yang 陽) }\end{array}$

A similar scheme is present in the following two lines:

$\begin{array}{llll}\text { object } & \text { verb } & \text { material } & \text { object } \\ \text { 茄子 } & \text { 敲 } & \text { 泥 } & \text { 罄 } \\ \text { “eggplant” } & \text { “to knock” } & \text { “mud” } & \text { "chime stone” } \\ \text { 冬瓜 } & \text { 撞 } & \text { 木 } & \text { 鐘 } \\ \text { “white gourd” } & \text { "to beat” } & \text { “wood” } & \text { "bell” }\end{array}$

Where these latter two lines are concerned, the second one gives away the key to understanding the first: we should start with the expression zhuang mu zhong 撞木鐘, literally “to beat a wooden bell," but here meaning "to swindle” or "to do something in vain." In light of this meaning, we understand that the first line

6 The whole Nancun Chuogenglu 南村輟耕錄 is available at https://ctext.org/wiki.pl?if=en\&res =389039 (17 December 2018).

7 Cai $(2007,193)$. 
acts only as a mirror to the one below it; its function is merely to anticipate and complement the action described in the second line. By contrast, the very last couplet is the clearest one, and for prosodic reasons, it is the centre of gravity for the whole poem, the part in which the solution is given away, the enigma unfolds, and the mimesis finally falls apart. Because of its position at the end of the poem, and because of its relative simplicity and intelligibility, the last couplet brings us to reconsider all the previous lines as its corollary. The clarity of the last two lines justifies all the unintelligible images encountered before, and the rhyming pattern of the whole poem somehow pulls all the images towards the last couplet.

What do we make of these poems? Judging by the contextual information provided, both cases were born as "conversational jokes," but since they have been put into written form, it is possible for them to be retold, and thus be turned into "canned jokes." 8 In theory, their canned nature makes them suitable for endless retelling, but in practice, as we have seen, the density of their culturally specific elements begs for close reading and explanation of almost every single line. If, on one hand, it is true that in so doing we betray the original intention of the text as the written record of an impromptu piece, on the other hand, this kind of dissection is necessary to bring out and understand the satirical elements. If we wanted to understand them in terms of the ideas elaborated by Highet, ${ }^{9}$ it would be easy to give in to the temptation of regarding them as form- or content-parodies of classical poetry. One should acknowledge, however, that poetry is nothing other than the main instrument by which satire is conveyed, and neither its idiosyncratic succinct style, nor its images and themes, are made the object of mockery by these two jokes. On the contrary, satirical poems make use of this style to carry out their mimesis, and in order to do so, they recreate mock-classical poems with the utmost respect for their terse language and ornate images. Their respect for the classical language is, however, of a practical nature, and essential for these two texts to function as jokes. For the Chinese reader, the first joke in particular represents a script violation regarding the authoritarian voice of classical Chinese poetry, whereas the second joke sounds more like a traditional satirical poem and less like a joke, while making good use of juxtaposed images in rhyming patterns. Their satire is at once particular and universal, since both jokes are directed against a single individual while at the same time depriving their target of any discernible personality or features. Ultimately, these poems do not preoccupy themselves with distorting reality, or with offering an alternative to it, but the book presents them as commentaries on events that happened, and not as fiction.

8 For a thorough discussion of canned jokes, see Attardo (1994, 298; 2001, 62).

9 Highet (1962, 80-106). 


\section{The duality of satire in jokes}

\subsection{Kind-hearted and ruthless satire}

Imposing a certain cultural model on a product of a different culture leads inevitably to oversimplification of the latter; nonetheless, a Chinese scholar, Jin Xinrong 金金榮㮡 $(2007,20)$, has tried to superimpose the Horatian/Juvenalian duality onto Ming and Qing fiction. In his opinion, the classic book The Scholars (Rulin Waishi 儒林外史) is the foremost example of Horatian satire, mild and light-hearted; on the other hand, the text What Kind of Book Is This? (Hedian 何典), written in Wu 吳 (Shanghainese) dialect, is a prime example of Juvenalian satire, cruel and ruthless. Analogously, Qi Yukun 齊裕焜 and Chen Huiqin 陳惠琴 $(1995,4)$ recognize the two poles of Chinese satire as the Great Preface (Horatian) and the writings of the Han historian Ban $\mathrm{Gu}$ 班固 (Juvenalian). The debate about which texts should be included in which category has been further extended by Chen Yingshi 陈英仕 $(2005,22)$, who believes that, apart from these two categories, there is a third, "yuyan category," in which all the faults and shortcomings of men are described in the world of spirits or of dreams.

$X L G J$ lacks cohesiveness; thus, it is better to analyse it as a collection of more than seven hundred microtexts which can coexist as part of a shared narrative or can be independent from each other. This also explains why, for different jokes, different kinds of satire are visible. Let us consider some examples.

\footnotetext{
There are three statues in a temple, arranged in this way: first Confucius, then Buddha, and then Laozi. A Daoist monk sees them and soon puts Laozi in the middle. A Buddhist monk passes by and moves Buddha into the middle. A Confucian sees this and, of course, he moves Confucius into the middle. The Three Sages tell each other: "We were doing so well, but if these petty men keep moving us, we will break!” (XLGJ 1985, 323; my translation)
}

A vivid picture comes to life in the space of only sixty-four characters. On the surface, the laughter comes from the overall absurdity of the situation, with us readers experiencing a violation of our script for the concept of a statue. The book is full of talking statues, objects, and body parts, and this joke can be included in the yuyan category. At any event, once we take away this aspect, we come to realize this: we are not laughing at the three statues, but rather they are laughing at us, they are criticizing the three clergymen's behaviour, and by extension the behaviour of all humanity. We can see that the three statues embody the spirit of sanjiaoheyi 三教合一 “three teachings as one," the perfect, harmonious synthesis between Daoism, Buddhism, and Confucianism advocated through the centuries; the petty, small-minded clergymen operate to create the opposite 
effect: division, contrast. Although this message is a serious one, it is delivered in a rather benign and light-hearted way: the Three Sages, without any reverential fear, address each other like old friends, with informal language (highlighted by the word haohao 好好, meaning “quite well," and by the pronoun women 我们, simply meaning "we," where the classical Chinese wording would have called for more venerable address forms).

Whenever the writer of these jokes adopts a benevolent attitude to satire, one characteristic is widespread in the jestbook: an eminent, authoritative voice delivers the punchline, in most cases Confucius himself. In "Visiting a Confucian Temple” (Ye Kongmiao 謁孔廟), Confucius, a statue once again, delivers a verbal pun based on the relationship between his surname Kong 孔 and the Chinese kongfang 孔方 coins. In "Presenting Evidence to Confucius" (Zheng Kongzi 證孔子), Confucius - this time in person - manages to solve a dispute between two Confucian scholars by flattering them both as orthodox interpreters of his doctrine, only to confess to his pupil that he did so only because he was fed up and wanted to get rid of them. ${ }^{10}$ We see Confucius; but onomasti komodein (criticizing someone by calling him/her by name) does not take place, because he is the one who criticizes and the "victims" are usually only called by their professions. In seeing Confucius, arguably one of the most authoritative characters in Chinese history, making such light-hearted remarks, the hypothetical Chinese reader experiences another script violation, which adds to the overall comic effect.

Ruthless and merciless satirical content can be found in poems as well as in ordinary jokes. What strikes us here is that the satirical element is not exactly part of the closing punchline (as happened in the two poems that we briefly analysed above), but is given away by some secondary detail. Doctors are a (negative) model character, and even though the jokes in which they appear are mostly variations on the theme of "a bad doctor kills a patient by malpractice," the punchline is not always a direct attack on them, and in some cases it can even be uttered by them. An example follows:

A child has a fever, and when the doctor gives him some medicine, he dies. His father wants to punish the doctor. The doctor does not believe him, so he goes to examine the child, touches him, and tells the father: "You really are a deceiver! You only wanted me to relieve his fever, and now that luckily all his body has turned cold, why are you blaming me?" (XLGJ 1985, 85; my translation)

10 Both jokes have been translated into English by Hsu (2015, 67, 82). Hsu's translation is based on the Xiaofu, and thus bears different titles and/or punchlines. 
The doctor's cunning reply makes the reader feel no pity for or empathy with him. The satirical element is represented by the doctor's quick-witted attempt to escape well-deserved punishment. The dominant character of the text as a mere joke is visibly at odds with the satirical element: the objective of the former is to amuse the reader, while the latter aims at scaring him/her, or at least causing him/her to loathe the doctor. The subjective aspect of the text comes to light, and the reader will decide whether to go all the way in interpreting the text as a violent attack on widespread medical malpractice, ${ }^{11}$ or to treat the text merely as a joke, laughing and forgetting about it soon after. Interestingly, the remark sounds ironic (and that is why it would make us laugh), but the irony is only external, by which I mean that, seen from the doctor's perspective, there is no irony in his words and he only wants to escape punishment.

\subsection{Realistic and exaggerated satire}

It is often said that satirists resemble prophets because they can foretell and narrate future events based on what they see in the present. Satirists put their society in front of a mirror, and let it look at itself from a detached point of view. It is necessary to note that XLGJ's approach to society is rather different: the only place in which the book tries to show us the future is in the description of a single person's future, more precisely in the afterlife:

A man who does not believe in Buddhism, after death suffers a severe punishment. Once arrived in hell, he tries to find a monk to obtain a good reincarnation, but he cannot find any. He asks someone: “So, aren’t there any monks here?” and the other soul answers: “Oh, there are many, but they are all sent to Fengdu [the capital of hell].” (XLGJ 1985, 261; my translation)

This kind of satire does not show us the effect of the monks' behaviour on future society, but rather on themselves. When we see the monks sent into the deepest pits of hell, the first thing that we can think of is, once again, a violation of the "monk" script. The world of spirits is much more widespread in traditional Chinese than images of talking animals, which are rarer here than in the Western tradition. ${ }^{12}$ The distorting mirror effect appears because we find one little-known element (the monk) which links the world of the joke with the actual world, so

11 Zhou (1983, 8-9).

12 Qi and Chen (1995, 57-58). 
that, rather than a critique of society, we get a critique of the Buddhist clergy. One might say that this is not pure satire but rather a "sour invective" (I borrow the term from Frye) because it does not offer the monks a chance for redemption. It is here that another dualistic aspect of jokes comes forward, and that is the duality of its recipients. If, on the one hand, the joke addresses the monks already beyond redemption with a purely derisive purpose, on the other hand, the joke indirectly addresses readers, and in a broader sense everyone who in theory can still be saved, with a didactic purpose.

Equally important, when XLGJ wants to criticize society directly (and bad doctors or magistrates as symbols of society), it does so without transposing the setting in space or in time; instead, it shifts our point of view by starting from a different context and moving back to the original. Once more, the world of spirits and demons is the preferred starting point:

The King of Hell sends a demon to the world to investigate a famous doctor, telling him: "You should look for the one without any spirit of a wronged patient waiting at his door." The demon understands the order and goes into the world, but in front of every doctor's office, he happens to find the spirits of many wronged patients. Finally, he arrives at a house before which he only sees the guardian spirit of the door walking back and forth, so he thinks: "This must be the place where the famous doctor operates." However, when he asks about it, it turns out that the doctor had just started practising the day before. (XLGJ 1985, 75; my translation)

This joke carries out a direct and explicit criticism of doctors; it only transposes the setting for a brief moment, before returning us to the real world. This has the effect of making the reader see the old world from a more detached perspective, and thus awakening the reader to the patients that are wronged by bad doctors every day.

Another interesting perspective is the one in which a character is stripped completely of all traits of personality and only two things remain visible in his/ her description: his/her social role and his/her obsession. We have seen before that magistrates and doctors are not called by name, and thus are epitomes of whole categories, and that monks are the ones who suffer this fate most often. Most jokes about monks rely on them having a double cross to bear, one because of their identity as monks, and another because of their lust and sexual desires:

One night, a Buddhist master tells his apprentice: “Tonight we'll be vegetarian!” When his apprentice asks: "What do you mean by vegetarian?" his master replies: "We will do it without saliva!" During the intercourse, the apprentice feels pain and screams: "Master, it's unbearable, please let's have some meat!” (XLGJ 1985, 262; my translation and emphasis) 
The text does not seem willing to develop the characters' different personalities, so they come across as one-dimensional marionettes, driven by one purpose only. By cutting out all other aspects of their personality, and focusing only on their bad habits, the text manages to magnify all condemnable behaviour, and brings to prominence hidden or dormant traits. Stories about lustful monks and nuns appear throughout the book (and actually have a prominent role in the literature of the time), and this exaggeration, while detracting from the characters' verisimilitude, certainly proves effective in creating an amusing effect. The Buddhist master could not have used different words for his description, since vegetarianism is an important part of Buddhist life, and the joke highlights the tension between the vocabulary which he (as a monk) has to adhere to, and the sexual impulses that lie within him (as a person).

\section{Conclusion}

Satire is one of the continuous features in Chinese literature. It should not come as a surprise, then, that even in jestbooks, a minor form of literature, the satirical element is present in various forms and configurations. As we have shown above, this element demands a close analysis in order to be understood and appreciated in its totality, and, rather surprisingly, shows continuous references to more orthodox literature and culture. Moreover, in order to discover these traits, one has to engage in a "misreading" of the original text. By this, we mean that we should neglect its primary function - that of being an amusing piece of writing and investigate the reasons behind the amusement it might create in a Chinese reader. Only by carrying out this misreading can we gain a clearer picture of the various features (not only satire, but also humour, carnival, the grotesque, parody, and so on) that are latent in this jestbook. Only by choosing not to laugh, can we discover and reveal the redemptive qualities of these particular pieces of Chinese satire.

\section{Works cited}

Attardo, Salvatore. Linguistic Theories of Humor. Berlin and New York: Mouton De Gruyter, 1994.

Attardo, Salvatore. Humorous Texts: A Semantic and Pragmatic Analysis. Berlin: De Gruyter, 2001.

Cai Zong-Qi, ed. How to Read Chinese Poetry: A Guided Anthology. New York: Columbia University Press, 2007. 
Chen Yingshi 陳英仕. Qing Dai Guilei Fengci Xiaoshuo Sanbuqu: Zhanguizhuan, Tangzhongkui Ping Gui Zhuan, Hedian 清代鬼類諷刺小說三部曲: 《斬鬼傳》《唐鍾馗平鬼傳》《何典》

[A Trilogy of Supernatural Satirical Novels from the Qing Dynasty]. Taipei: Showwe Information, 2005.

Chen Puqing 陳蒲清 and Cao Risheng 曹日升. “Shi Lun Zhongguo Gudai Yuyan De Fazhan Jiqi Tese” 試論中國古代寓言的發展及其特色 [An Attempted Commentary on the Development of Ancient Chinese Parables and Their Features]. Qiusuo 求索 4 (1981): 119-124.

Confucius. The Analects (New Bilingual Edition). Trans. D. C. Lau. Hong Kong: Chinese University Press, 2010.

Eco, Umberto. The Role of the Reader. Bloomington: Indiana University Press, 1979.

Guo Qingfan 郭慶藩. Zhuangzi Jishi 莊子集釋 [Complete Commentaries on Zhuangzi]. Ed. Wang Xiaoyu 王孝魚. Beijing: Zhonghua Shuju, 1985.

Highet, Gilbert. The Anatomy of Satire. Princeton: Princeton University Press, 1962.

Hsu Pi-Ching. Feng Menglong's Treasury of Laughs: A Seventeenth-Century Anthology of

Traditional Chinese Humour. Leiden: Brill, 2015.

Jin Xinrong 金金榮. Ming Qing Fengci Xiaoshuo Yanjiu 明清諷刺小說研究 [Research on Satirical Novels of the Ming and Qing Periods]. Beijing: Fenghuang Chubanshe, 2007.

Knechtges, David R. "Wit, Humor and Satire in Early Chinese Literature (to A.D. 220)." Monumenta Serica 29 (1970-1971): 79-98.

Owen, Stephen. Readings in Chinese Literary Thought. Cambridge and London: Harvard University Press, 1992.

Owen, Stephen. The Poetry of Du Fu. Boston and Berlin: De Gruyter, 2016.

Qi Yukun 齊裕焜 and Chen Huiqin 陳惠琴. Jing Yu Jian: Zhongguo Fengci Xiaoshuo Shilüe 鏡與 劍: 中國諷刺小說史略 [The Mirror and the Sword: A Brief History of the Satirical Novel in China]. Taipei: Wenjin Chubanshe, 1995.

Rea, Christopher. The Age of Irreverence: A New History of Laughter in China. Oakland: University of California Press, 2015.

Wang Liqi 王利器. Lidai Xiaohua Ji 歷代笑話集 [A Collection of Jokes through the Ages]. Shanghai: Gudian Wenxue Chubanshe, 1956.

Xialoin Guangji = Xinjuan Xiaolin Guangji 新鑴笑林廣記 [Newly Carved Extended Collection of the Forest of Laughter]. Ed. Youxi Zhuren 遊戲主人 and Research Center of Classical Literature at National Cheng Chi University 國立政治大學古典小說研究中心. Taipei: Tianyi Chubanshe, 1985.

Zhou Qiming 周啟明, ed. Ming Qing Xiaohua Si Zhong 明清笑話四種 [Four Kinds of Jokes from the Ming and Qing Periods]. Beijing: Renmin Wenxue Chubanshe, 1983.

Antonio Leggieri was born in Grottaglie in 1987, and holds an MA in Editorial and Sectorial Translation and Interpreting (Chinese and English into Italian), and a $\mathrm{PhD}$ in Comparative Literature and World Literature from Beijing Language and Culture University. He is currently a candidate for a second $\mathrm{PhD}$ at the University of Salento (Lecce, Italy); his current research focuses on premodern Chinese literature. 